\title{
Ecology, Love, and Relationships in Sir Philip Sidney's Astrophil and Stella
}

\author{
Gül Kurtuluş \\ Bilkent University, Ankara, Turkey
}

\begin{abstract}
One of the threats to the modern men today is the quick change in seasons and unusual fluctuations in temperature. Contemporary life is marked with various conditions that make life comparatively different and for that matter difficult for everyone. Amongst many worldly things, like materialism, struggle to survive in the highly competitive urban settings, people tend to consider the merits of cosmopolitanism more than anything else. Curiously enough, Sir Philip Sidney's sonnets, though written in the 16th century and become milestones of the sonnet tradition in the English Renaissance which are applicable to today's global concern of environmentalism. When considered in the light of ecocriticism, Sidney's sonnets provide a suitable ground for the modern readers to reevaluate the current situation of the world we live in and the nature that we inherit from our ancestors. This paper aims to analyze some of Sidney's selected sonnets from Astrophil and Stella in the light of ecocritical approach to literary works.
\end{abstract}

Keywords: Sir Philip Sidney's Astrophil and Stella, environmentalism, nature and man, love and nature, global warming and poetry

\section{Introduction}

Nature has always been of interest for human beings in all ages. No matter how many ages and centuries have passed since the initial concerns of people deal with changes in natural order, sudden changes of climate and of seasons as seen in the examples in the 16th century examples, we are still concerned with the same problems, even more than ever. This paper aims to consider Sidney's selected poems from Astrophil and Stella from an ecocritical perspective. It is one of the aims of the paper to provide an ecocritical reading of Sidney's sonnets, which might prove to be creative, thought-provoking, and interesting for the modern reader. Sidney's sonnets are almost always associated with love tradition which is frequently employed in the 16th century. The new approach of this paper will enable the readers to see the sonnets in the light of ecocritism.

\section{Ecology and the Sixteenth Century Sonnets}

A wide spectrum of themes bearing on nature and ecology is used in the poetry and drama of the 16th century. The characters created by playwrights and poets, the conflicts in settings that range from the global to the local, and the highly metaphoric language used in plays and poems still astonish readers who deal with

Gül Kurtuluş, Ph.D., English Language and Literatüre Department, Faculty of Humanities and Letters, Bilkent University. 
environmental issues today. As early as the 16th century, the tension between technological developments and the controlling organic images in the world of the mind became too great for harmony between people and nature. Today, human beings are involved in global warming with the quick melting of polar ice caps, the over-exploitation of natural resources, drastic migration for better living conditions, and the depletion of energy resources. It seems humanity may still be dealing with such matters, or worse, in the coming decades and beyond. In spite of changes of mindset since the 16th century, some events still have parallel repercussions on human beings' lives. It is enriching to see that sixteenth-century sonnets are not only about the conflicting feelings of a lover who lives through hope and wretchedness, compassion and lack of affection or rejection, exultation and simplicity, but also about the changing conditions of the world, especially in terms of environmental issues and male-female relationships. Such an understanding may enable modern readers to look at the sonnets in a new way as relevant to them five centuries later.

The effects of changing conditions in human life, soul and environment, and the imbalance in nature and climate, as exemplified in Sidney's sonnet sequence Astrophil and Stella will be foregrounded in this paper. Modern readers' perceptions of sixteenth-century sonnets in the light of the twenty-first century's hot debates, such as conserving our remaining energy resources and ending the extravagant use of natural riches, will be considered. Like other Elizabethan sonneteers, Sidney makes use of a wide range of motifs from everyday life, including the natural world. In Sonnet 97, Shakespeare employs nature as a power that shows its beauty and ugliness at the same time:

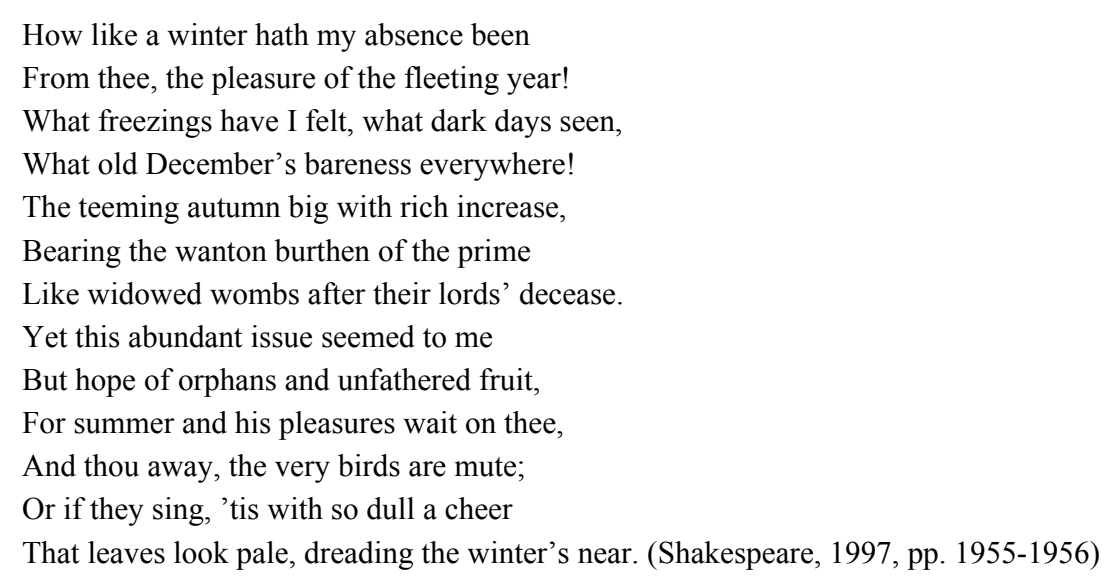

The speaker reveals his sense of death by likening himself to autumn in which nature's objects such as flowers or grass begin to fade as winter is so close. Winter has the freezing power, as well as dark days, similarly, the speaker's soul is lost in the darkness of winter. His separation from the young man is reminiscent of the freezing days of December. Birds are mute, trees are barren, leaves are fearful of the winter's coming. Sonnet 97 is based on the imagery drawn from nature and the poet makes use of this imagery profoundly. Imagery drawn from nature, such as the sun, sea, seasons, and flowers, are central to Sidney's sonnets. All the images of nature employed in his verse appeal to the five senses as well as to the thinking faculty which is peculiar to Sidney, apparent in the depiction of the clash between the soul and the mind. Beyond that, making symbolic connections is the primary mode of thought in the English Renaissance and Sidney is one of the sonneteers who makes use of the symbolic connections extensively in his sonnets. M. C. Bradbrook (1979) in Shakespeare and Elizabethan 
Poetry states that "the essential point was that nature, being the art of God, was both many and one, and that all the meanings of symbol were necessary to an understanding of the fact in its universal implications" (Bradbrook, 1979, p. 9), a view that clarifies the generally accepted notion by medieval and almost all early modern poets who grasped nature as God's art. God created the natural world according to a certain order in which his wisdom can be discerned. The desire to find patterns and correspondences in nature, often related to the Elizabethan idea of the Great Chain of Being, has been most famously outlined in E. M. W. Tillyard's (1972) The Elizabethan World Picture (Tillyard, 1972, p. 33). God has the highest position in the chain of beings and he is the creator who puts everything in its right position in this chain, at the bottom of which lies the lifeless objects. Plants and animals come before the inanimate beings. The chain is formed in the order that put mankind below nature. Angels come before nature and lastly God takes the highest position. The chain of beings binds everything together in unity and in a hierarchy which mirrors the ideal of social and universal order of the time. The Elizabethan view of nature dictates that nature is created by God and is the ultimate perfection and reflection of God, a view that clarifies man's lack of control over nature as opposed to God's control and presence, ever felt through nature. As an Elizabethan sonneteer who makes use of nature in his sonnets, Shakespeare talks about imperfection in Sonnet 35. The persona in this sonnet gives examples of natural faultiness. "Roses have thorns, and silver mountains mud, / Clouds and eclipses stain both moon and sun, / And loathsome canker lives in sweetest bud" (Shakespeare, 1997, pp. 1934-1935). Man is apt to make mistakes, just like faults found in nature. As seen in the close relationship between man and nature, they are very much dependent on each other. By considering this vision of man and nature in the 16th century, we become aware of the instructiveness in re-interrogating man and nature correlation as well as revitalizing ecological consciousness in human beings.

\section{Nature as the Essence of Everything in Sir Philip Sidney's Poetry}

In Sidney's sonnet sequence, Astrophil and Stella, the term nature is not used to describe the natural phenomena of the sky and the countryside, and what is seen there. There is a relationship in which the ordering force of reason is brought to bear on the disordered, respecting the proper function of each lesser aspect or being. The parallelism of disordered human nature and untamed, wild nature is a central characteristic of the sonnets. Art and nature exist in a creative tension in Sidney's sonnets, and the aspect of art which is most closely related to nature is the poet's use of natural images. Nature is considered as a main source of the imagery of Sidney, a sonneteer who is a keen observer of the natural world. Sidney observes the beauty, scent, and the colours of the flowers, the movements of the birds and clouds, the sun, moon, and the sky, and finally he observes the changes of seasons. By creating a resemblance between his beloved and nature, the persona elevates his beloved Stella's beauty or personality to a rank higher than that human beings usually occupy in the chain of being, and thus illustrates how beautiful, gracious, and virtuous Stella is as a part of the perfection of nature.

There is no art delivered to mankind that hath not the works of Nature for his principal object, without which they could not consist, and on which they so depend, as they become actors and players, as it were of what Nature will have set forth. ${ }^{1}$ (Dutton, 1987, p. 106)

\footnotetext{
${ }^{1}$ All references to Sir Philip Sidney's sonnet sequence will be from Selected Writings: Astrophil and Stella, The Defense of Poesy and Miscellaneous Poems, edited by Richard Dutton (1987) in the page 106. Subsequent references to Sidney's sonnets are from this edition.
} 
Sir Philip Sidney, the author of this quotation, writer of a pastoral romance, Arcadia, and the Renaissance man to whom Edmund Spenser dedicated The Shepheardes Calender, conveys his ecological awareness in his works and has a rightful place among the forerunners of ecological writing. As one of the prolific poets of the 16th century, Sidney authored the first and most important sonnet cycle, Astophil and Stella, which is composed of 108 sonnets and 11 songs. While Shakespeare's works have been the subject of numerous ecocritical studies, Sidney's poetry has not, to date, been read in such terms. However, his sonnet sequence provides evidence of the close attention Renaissance writers gave to man's collaboration with earth, long before the ecological crisis reaches its climax. This paper challenges interpretations of the 16th century English sonneteer Sidney's Astrophil and Stella in reconstructing Renaissance ideas about nature. For him:

Only the poet, disdaining to be tied to any such subjection, lifted up with the vigour of his own invention, doth grow in effect into another nature, in making things either better than Nature bringeth forth, or, quite anew-forms such as never were in Nature, as the Heroes, Demigods, Cyclops, Chimeras, Furies, and such like; so as he goeth hand in hand with Nature, not enclosed within the narrow warrant of her gifts, but freely ranging only within the zodiac of his own wit. Nature never set forth the earth in so rich tapestry as divers poets have done; neither with so pleasant rivers, fruitful trees, sweet-smelling flowers, nor whatsoever else may make the too much loved earth more lovely. (Dutton, 1987, p. 107)

Sidney bestows a responsibility on the poet to represent virtues and vices in a more lively and telling way than nature does. Thus, in his attempt to defend the poet he places the poet above nature, and therefore the creator. In trying to preserve what has been created, the environmentalists assign human beings a role above and beyond nature, in just the way Sidney describes the poet's function.

Nature stimulated the imagination of Sidney, as it did many other Renaissance writers. In the Elizabethan era, with new specimens being discovered in new lands, interest in nature increased. Botanical studies as well as anatomy studies led to a new fascination with the universe, the world, and humanity. Analyzing ancient art and sculpture made Renaissance artists question scholastic thought about nature, and experimenting with nature became more frequent. Nature became a way of broadening the human imagination and a sign of perfection, whereas humans were seen as deficient in nature's qualities, as indicated in the theory of the great chain of being. Yet, there is a belief in human progress in the early modern period, unlike in the Middle Ages. The Renaissance is a period that attaches importance to nature because it comes after the war, disaster, death, and famine of Medieval Europe. With this new era, nature and its significance in human life started to be reconsidered and examined, a movement that is also reflected in the poetry of the period. Shakespeare's Sonnet 73 is one of the sonnets which focuses on the persona's thoughts on his own mortality, in which man's place in nature is handled in accordance with the damage that time gives to one's physical appearance and mentality as one gets older and time draws near for the ultimate end. The physical act of aging, final act of dying and change in time that devours everything including nature and natural elements are all transitory phases illustrated together with the objects, susceptible of change in this sonnet:

That time of year thou mayst in me behold

When yellow leaves, or none, or few do hang

Upon those boughs which shake against the cold,

Bare ruined choirs, where late the sweet birds sang.

In me thou seest the twilight of such day

As after sunset fadeth in the west 
Which by and by black night doth take away,

Death's second self that seals up all in rest.

In me thou seest the glowing of such fire,

That on the ashes of his youth doth lie

As the death-bed whereon it must expire,

Consumed with that which it was nourished by.

This thou perceiv'st, which makes thy love more strong,

To love that well which thou must leave ere long. (Shakespeare, 1997, p. 1947)

Amongst the different meanings of the term nature in the Renaissance, a particular use of it is noteworthy, as the universe or the sum of things. Nature is the essence of things hidden under the veil of particulars. Nature is empirical reality, especially that of the typical characters, actions, and passions of man. What is called renaissance naturalism is an imitation of nature, which requires remaining faithful to the main object. Idealism is also part of the teachings of the Renaissance idea of perfection, which is rooted in the notion of development. The idea of perfection is reflected in the arts, and contributes to the birth of Renaissance classicism. In simple terms, it is the interaction of this naturalism and this realism, culminating in a "perfect" representation of nature which is simultaneously the quintessence of reality. While the work represents nature through imitation, it should re-present a perfect and idealized nature. In making resemblances between the beloved and the objects found in nature Renaissance poets tend to objectify their beloveds. Nevertheless, nature will always be more effective and remain as the most powerful object. In Sidney's Astrophil and Stella, Stella is associated with a star. Astrophil is not able to reach Stella, who is part of the nature that is above mankind. Stella belongs to a perfection that is created and can be controlled only by God. She is beyond Astrophil's human boundaries and rank in the universe, which is equal to the idea of placing nature above the rank of human beings in the chain. In the Elizabethan world-view, human beings possess the utmost capabilities such as virtue, love, perfection, desire, and other qualities derived from nature. However, these qualities are incomplete, and human beings have limited capabilities. It is believed that every creature is guided by one principle, and people are pulled in different directions by different faculties, sometimes drawn towards the better, at other times towards the worse.

\section{Sidney's Language and Nature}

In Sidney's sonnet sequence, the stages of the love relationship can be traced from the lover's initial interest in the lady, his appreciation of her physical beauty, to his many sided attempts at persuasion and his sufferings, to a finale where nothing is resolved. In Astrophil and Stella, Sidney's language is full of conceits and allegories. Nature is seen as the essence of everything in his poetry. In the first sonnet of the sequence the persona expresses his wish to find "fit words to entertain lady's wit". In his search for help he requires "Invention's stay" to make the beloved aware of his suffering:

Loving in truth, and fain in verse my love to show,

That the dear she might take some pleasure of my pain,

Pleasure might cause her read, reading might make her know,

Knowledge might pity win, and pity grace obtain,

I sought fit words to paint the blackest face of woe:

Studying inventions fine, her wits to entertain,

Oft turning others' leaves, to see if thence would flow

Some fresh and fruitful showers upon my brain. 
But words came halting forth, wanting Invention's stay; Invention, Nature's child, fked step-dame Study's blows, And others' feet still seemed but strangers in my way. Thus great with child to speak, and helpless in my throes, Biting my trewand pen, beating myself for spite,

"Fool," said my Muse to me, "look in thy heart and write". (Dutton, 1987, p. 29)

He defines Invention as "Nature's Child", which proves to be an allegorical example. Sidney's conceit in lines seven and eight is reminiscent of contemporary humanity's dilemma, and even its despair, as dry, waterless lands under the scorching effect of sun yearn for refreshing showers. His choice of Nature as a term for the life-giving force is deliberate, since he accepts it as origin of everything in the universe. The world, then is seen as an organic whole and not as a machine as it will later become when it is viewed as the product of later capitalist society. The typical Elizabethan view of nature was that of the manifestation of God who had stamped a designed order on the world. In such an order, human beings had to follow ethical norms of behavior. They had to recognize their place within the pattern of the natural order. Each organic creature, from plants to animals, from human beings to celestial beings, had to maintain its own place and was regarded as an inevitable part of the whole. Thus, the harmony and the balance of the whole was preserved due to the self-restraint of each being. Nature was the instrument of God's expression in the world. God revealed his skill through nature. As Carolyn Merchant (1989) explains in The Death of Nature:

Beyond the planets was the sphere of the primum mobile, source of the daily rotation of the heavens, then the sphere of the fixed stars and zodiacal constellations, and finally the Emphyrean heaven of God. Together they comprised a living chain of being, each member a step in a stable, ordered, spherically-enclosed world, each member sharing some particular feature with the steps below and above, yet excelling in some unique characteristic... Nature as the involuntary agent of God was the immanent manifestation of God's law in the world. (Merchant, 1989, pp. 100-101)

Sidney's perspective on nature is not very different from the Elizabethan belief regarding nature which focused on nature's effect on art and human capabilities. In the imitation of nature, the creator is the poet, and poetic justice is carried out by nature. Philosophers follow nature, whereas poets filled with the vigor of the poet's invention make things seem better than what nature brings forth, even making things appear as never seen in nature. In accordance with this view, Sidney's sonnets nature is personified, and is the force which shows virtue and reason to Stella. Nature acts like a character that teaches morality and goodness as well as perfection in life. In Sonnet 71, the lover's state of being defeated by emotions as he lets go of his reason is depicted through the lover's inability to reach the star:

\footnotetext{
Who will in fairest book of Nature know, How Virtue may best lodg'd in beauty be, Let him but learn of Love to read in thee, Stella, those fair lines, which true goodness show. There shall be find all vices' overthrow, Not by rude force, but sweetest sovereignty Of reason, from whose light those night-birds fly; That inward sun in thine eyes shineth so. And not content to be perfection's heir Thyself, doest strive all minds that way to move: Who mark in thee what is in thee most fair.
} 
So while thy beauty draws the heart to love,

As fast thy Virtue bends that love to good:

"But ah," Desire still cries, "give me some food". (Dutton, 1987, p. 65)

Stella works together with nature's good qualities, but neither shows the way to reach the right destination nor nurtures the lover. In line with Sidney's belief about nature and how poetry is the imitation of nature, Sonnet 71 employs Nature, Beauty, and Reason as allegorical characters. In Sidney's imagination, the imitation of nature is composed of such personifications. Man is inferior to nature and the star-lover is inferior to the star.

\section{From Harmony to Disorder, From Partnership to Rivalry}

After the Industrial Revolution, though, human beings viewed themselves as the administrators of nature, as opposed to the earlier Renaissance view of the position of human beings in the order of the universe (Naess, 1992, p. 187). Inevitably, a transition from harmony to disorder, and from partnership to rivalry or a high commercial state has been experienced. Some interpretations of the Bible suggest that human beings are given equal rights with the other creatures by God. The human function as guardian or keeper is always of great importance to ecological thought. However, as Naess (1992) ironically argues "our responsibility today, is not that of a guardian of the natural world, but that of the thief and manipulator" (Naess, 1992, p. 187). Unlike the general understanding of human beings' place in nature in the 16th century, Naess interprets modern people's interaction with nature as harmful, since human beings are not aware of their responsibilities. Naess (1992) points out that the arrogance of stewardship consists in the idea of superiority which underlies the thought that we exist to watch over nature like a highly respected middleman between the Creator and the Creation. We know too little about what happens in nature to perform the task satisfactorily (Naess, 1992, p. 187). Human beings can extend the idea of being the administrators of domestic animals and agricultural land to vaster spaces, and this may lead to an awareness of ecological responsibility. Otherwise, man's harmony with nature and his attempts to live in conformity with nature, as practiced in early modern times, will prove to be a compromise which is far ahead of the situation in today's world.

In Sidney's sonnet sequence we read of the persona's perpetual wish to be with Stella, together with references to natural imagery. While expressing his yearning for the lady he uses natural images which draw a parallel between the way one may see human beings' treatment of nature and ways of seeing the beloved. Once adored by people who were aware of their place in the natural order, nature is usurped by them, with disastrous consequences today. The lady is wooed by the lover who tries to convince her to be with him. Her beauty is cherished in line after line. Sidney depicts Stella's beauty as a pure and perfect product of nature, which is generous in its nurturing quality. In sonnet nine, Stella's face is compared to Queen Virtue's court. Such an analogy suggests Stella's unreachable beauty and her virtue, regarded as her outstanding feature:

Queen Virtue's court, which some call Stella's face,

Prepar'd by Nature's chiefest furniture,

Hath his front built of alabaster pure;

Gold is the covering of that stately place.

The door by which sometimes comes forth her grace,

Red prophyr is, which lock of pearl makes sure:

Whose porches rich (which name of cheeks endure) 
Marble mixt red and white do interlace.

The windows now through which this heav'nly guest

Looks over the world, and can find nothing such,

Which dare claim from those lights the name of best

Of touch they are that without touch doth touch,

Which Cupid's self from Beauty's mine did draw:

Of touch they are, and poor I am their straw. (Dutton, 1987, p. 33)

In the sonnets following this comparison Sidney's use of color imagery can be interpreted in various ways. Black is the color of woe; however, Stella has black eyes which are extraordinarily beautiful and bright enough to make "all beauties flow" in black, as shown in sonnet 7 (Dutton, 1987, p. 33):

Or would she [Nature] her miraculous power show,

That whereas black seems beauty's contrary,

She even in black doth make all beauties flow? (Dutton, lines 9-11, p. 33)

The first line of the same sonnet celebrates Stella's eyes as significant works of Nature:

When nature made her chief work, Stella's eyes,

In colour black, why wrapped she beams so bright? (Dutton, lines 1-2, p. 33)

It is evident that Stella's eyes are the creation of Nature, which implies that though they are black, they are not ugly but beautiful shining eyes that remind us of the power of Nature. In Sidney's sonnet, the modern reader perceives the variety in the use of colors as one of the images derived from natural sources. Such imagery enables the reader to consider the lover's desire to be accepted by the lady as partly parallel to the longing to reach perfection and balance in nature. The lover's notion of having an intermediary place between the Creator and the Creation makes him both an admirer and a close follower of the lady. Since the lady is associated with nature, in accordance with her nurturing and life-giving qualities, the lover's wish to be accepted by the lady is equivalent to a desire to maintain harmony with nature. The lover seeks his place in the cosmos in relation to both the lady and nature. The Elizabethan idea of the Great Chain of Being claims that the universe has a unity, yet still there is fragmentation in it as every object has a class above it, and another below it. E. M. W. Tillyard (1972) in The Elizabethan World Picture describes to man's understanding and his place in the universe:

Man's understanding, though allied to the angelical, operates differently. The angels understand intuitively, man by the painful use of the discursive reason. Again, the angels have perfected their understanding and are replete with all the knowledge they are able to hold. Man, even though he may in the end rival the angels in knowledge, begins in ignorance. What marks man from angel and beast is his capacity for learning: both his "erected wit" in perceiving perfection and his aptitude for "nurture" or education in his raising himself towards it. Hence it was that the learning of a Sidney, a Donne, or a Milton was an ethical and religious matter. (Tillyard, 1972, p. 79)

Man excels the angels in his power of learning, for his very imperfection calls forth that power. Therefore, the psychology and potentiality of human beings are given value in this period. The focus is on man as the measure of all things. Sir John Hayward quotes from David's Tears (1623, p. 168): "Thou art man, endured with reason and understanding, wherein God hath engraven his lively image. In other creatures there is sonic likeness of him, some footsteps of his divine nature; but in man lie hath stamped his image" (Tillyard, 1972, p. 122). Here, we can understand that man is the prince of all creatures as he is the image of God on earth and he has an 
important ability to control Nature. Sidney emphasizes the necessity of using Nature or elements of Nature in sonnets as he believes that man can perfectly shape these elements by ascribing different meanings to them and they can create their own nature in their poems. In his Defense of Poesy, Sidney says:

Neither let it be deemed too saucy a comparison to balance the highest point of man's wit with the efficacy of Nature; but rather give right honor to the heavenly Maker of that maker, who having made the man in His own likeness, set him beyond and over all works of that second nature [i.e. physical nature]; which in nothing he showeth so much as in Poetry, when with the force of a divine breath [inspiration] he bringeth things forth far surpassing her doings, with no small argument to the incredulous of that first accursed fall of Adam - since our erected with maketh us know what perfection is, and yet our infected will keepth us from reaching unto it. (Dutton, 1987, p. 108)

Rather than slavishly looking to nature for his subject, the poet turns to his own mind. It is there and not within the narrow warrant of Nature's gifts that he finds his subject. By inventively imitating nature in his sonnets Sidney idealizes nature.

\section{Reading Astrophil and Stella as Pastoral}

When pastoral is defined and used to refer to any movement from city to country, it may not evoke the intention of Sidney in his sonnet sequence. "Pastoral is essentially a discourse of retreat which may, as we have seen, either simply escape from the complexities of the city, the court, the present, "our manners", or explore them" (Gifford, 1999, p. 46). Sidney's Astrophil and Stella can be read as pastoral; it is clear that Sidney's poems have analogies drawn from natural settings and creation. The pastoral mode is wide-ranging and versatile. As Terry Gifford calls Shakespeare's plays such as As You Like It, The Winter's Tale and to add more to the list we can name The Tempest as pastoral, as well as many Romantic poets' works as pastoral, it would not be far-fetched to define Sidney's sonnet sequence as a literary work that functions in accordance with pastoral manifestations.

The essential paradox of the pastoral [is] that a retreat to a place apparently without the anxieties of the town, of the court, or the present, actually delivers insights into the culture from which it originates. Thus the pastoral construct always reveals the preoccupations and tensions of its time. (Gifford, 1999, p. 82)

Sidney's Nature is associated with kindness rather than revenge and Stella, who has been wooed in various ways, does not embody feelings of revenge. She is the product of Nature, so her qualities reflect the affirmative qualities of Nature. Yet, she resists Astrophil's insistence on having an affair before it is too late. Sidney's characters are not shepherds and shepherdesses as is the case with Virgil, one of the most influential classical exemplars of pastoral poetry. Still, the idealization of the love relationship and the wish to come to terms with the beloved evoke a similar atmosphere to that depicted by Christopher Marlowe in "The Passionate Shepherd to His Love". When the three orientations of pastoral in relation to time, as specified by Greg Garrard are considered, it is possible to infer that all three stages are exemplified in Sidney's sonnet sequence in just the way they are present in Virgil's Eclogues: "the elegy looks back to a vanished past with a sense of nostalgia; the idyll celebrates a bountiful present; the utopia looks forward to a redeemed future" (Garrard, 2005, p. 37). Sidney's poetry can act as an initiation into utopian promise as well as an elegiac commemoration: It even celebrates the present idyllic moment.

Sidney does not depict the "nature" that is seriously damaged by its inhabitants. On the contrary, in his sonnet sequence the persona seeks harmony with the beloved, the way a reconciliation is established between 
nature and its inhabitants since classical times. Such an agreement with Stella is the long-awaited wish of Astrophil. The lover's wish for an amorous relationship with the beloved parallels the situation of the fallen human soul and the fallen desecrated earth illustrated in Dante's Divine Comedy. Dante plays a critical role in establishing the interpretation of the Fall from Eden. The one who is to blame is Eve for the Fall and Adam who has paid the penalty for his sin has been redeemed and is rewarded with a dwelling in heaven. Stella is to be blamed for her resistance to the love of Astrophil and the outcome will be the tragic case of the unresolved love affair. The Renaissance, with its great inventions of the printing press, the compass, and gunpowder helped to propel the explorations of the New World, but at the same time led to a great transformation. A man-made, new social order replaced the uncultivated, untouched but pure balanced state of nature. Thus the Fall and Salvation were experienced simultaneously, as was the feeling evoked by Sidney's poetry when Astrophil seeks Stella's approval and consequently harmony, and ends up with unresolvable case of love.

In Sonnet 12, an example of the relationship between nature and humanity is given. Sidney refers to Cupid, the god of love and desire, a personification which adds a dramatic effect:

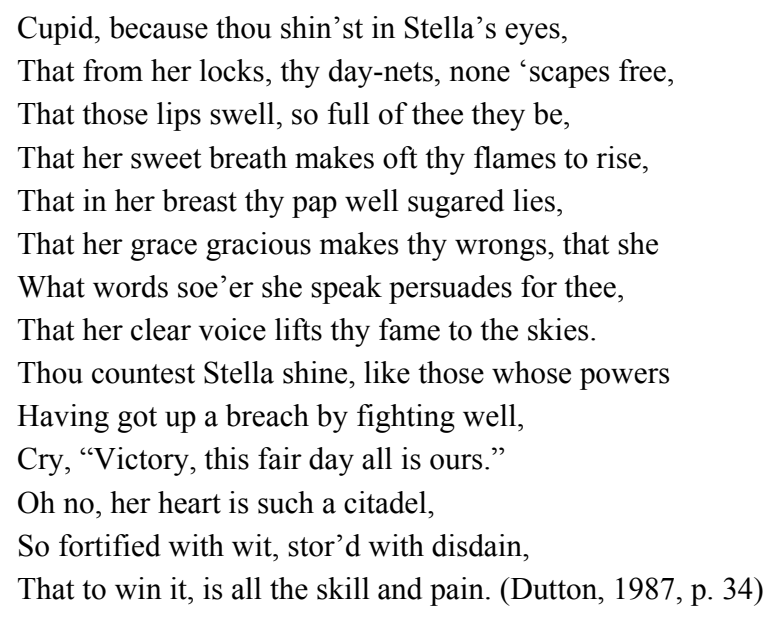

Renaissance humanism claims that human is the measure of all things in the universe. If it were not for Astrophil's emotions Stella's eyes would not shine with love. The position of the sun in the middle of the heavens and of the heart in the center of the body establishes an analogy between humanity and the natural world. Each respectively provides the basic needs for its system's survival. The order of nature and the order of humanity are the same, as both of them were created by God in a unified universe in which everything is linked and God's presence can be seen in everything he creates.

The second line of Sonnet 12 tells "That from her locks, thy day-nets, none 'scapes free"” (Dutton, 1987, p. 34). Stella's long and beautiful hair attracts the attention of everyone and tempts everyone like a net used to catch birds. Stella is again represented as part of nature and Astrophil's desire as being to seize and gain control of nature through his lusty desire.

The sixteenth-century verse tradition symbolized nature as a benevolent female, abundant examples of which can be found in pastoral poetry, as well as in sonnet sequences.

Pastoral poetry and art prevalent in the Renaissance presented another image of nature as female - an escape backward into the motherly benevolence of the past. Here nature was a refuge from the ills and anxieties of urban life 
through a return to an unblemished Golden Age. Depicted as a garden, a rural landscape, or a peaceful fertile scene, nature was calm, kindly female, giving of her bounty. (Merchant, 1989, p. 7)

Sidney conceptualizes nature in terms of both nurturing and the active, vital characteristics of the female body. In Sonnet 16 he announces his admiration of the lady's beauty:

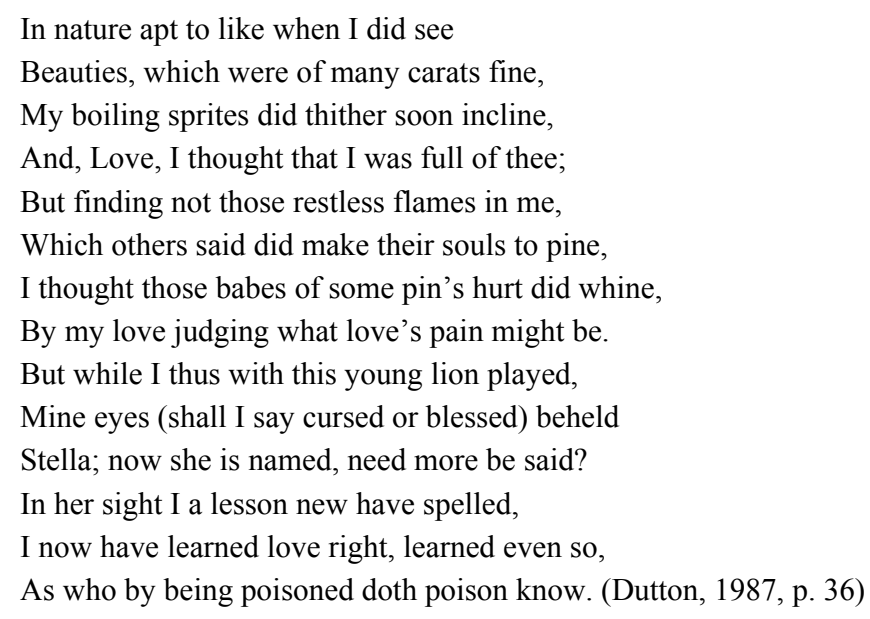

Similarly, the rhetorical question that begins Sonnet 71 leads the person who wants to find both beauty and virtue residing in one body in the fairest book of Nature to read true goodness in the "fair lines" of Stella:

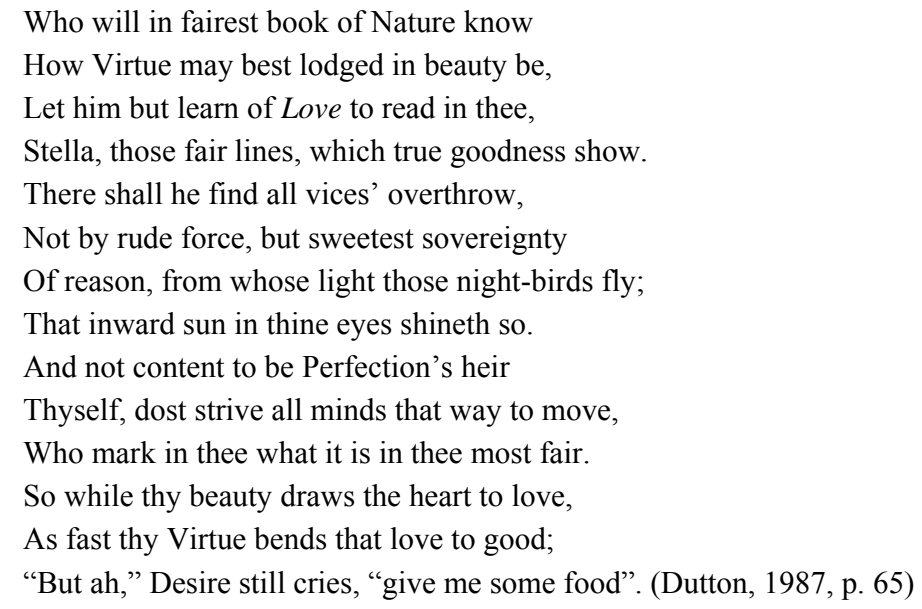

Stella is depicted as the writing in the "fairest book of Nature". Nature produces good works which are appreciated by the lover. As before, nature is not human nature but the initiator of all things. In sonnet 9, Stella's face, which is compared to Queen Virtue's court, has all the ornaments and riches of a court. The red of porphyry, the white of pearl, and the yellow of gold are examples of natural beauties. Such a picture inspires readers to be in harmony with nature. In order not to disturb the balance in nature, human beings need to reaffirm their roles as protectors and lovers of nature. Like the lover who woos the lady, human beings may be persuaded to come to terms with nature again. For some people the task is indeed persuasion, since there have been anti-ecologist movements that devote themselves to a full belief in materialism. There are supporters of technological and commercial development regardless of the negative consequences on earth. Lynn White Jr. offers an interesting 
suggestion in the 1967 publication of his paper "The Historical Roots of Our Ecological Crisis" in Science: "More science and more technology are not going to get us out of the present ecological crisis until we find a new religion, or rethink our old one" (Lynn, 1967, p. 2). If Christianity in the western tradition initiates harmony with nature, it is indicted for causing the western environmental crisis by White. Merchant (2004) in her book Reinventing Eden: The Future of Nature in Western Culture, proposes five precepts for a partnership between earth and humanity:

(1) Equality between the human and nonhuman communities;

(2) Moral consideration for both humans and other species;

(3) Respect for both cultural diversity and biodiversity;

(4) Inclusion of women, minorities, and nonhuman nature in the code of ethical accountability;

(5) An ecologically sound management that is consistent with the continued health of both the human and nonhuman communities (Merchant, 2004, p. 224).

The idea of seeing nature as a partner at the table indicates equality. Only through regression from consensus, into contention and thence into litigation is this partnership apt to be damaged. A partnership ethic goes beyond egocentric, androcentric, and anthropocentric ethics. Astrophil's urge to make Stella his ally, rather than an opposing partner, paves the way to Sidney's example of the inter-play between nature and art. It provides a good example of the ecological onus of Renaissance poetics and a precedent for ecocriticism's reconsideration of the mutually constructive relationship between nature and culture.

Renaissance thinkers believed that natural law could manage to rule and control nature, both in the sense of nature and human nature, and both of which were capable of redemption. The unruly and unpredictable form of nature needed to become the predictable. As Tillyard (1972) explains in The Elizabethan World Picture,

Count Hannibal Romei in the usual manner ascends the ladder of creation but above man and below the angels he puts Nature as an intellectual being. She is Plato's "Soul of the world" and as such gives life and shape to it. As nature, she "imprinteth into matter with the seal of divinity all forms generative and corruptible." As Intelligence, she is unerring and "directeth everything deprived of understanding to their end." Above Nature there follow the angels arranged in the Dionysian order... The Elizabethans talked much about nature, and she cannot be omitted from the world picture. That there was a law of nature was universally agreed; she worked unswervingly by a set of rules applicable to her alone. (p. 54)

Very briefly put, nature's chaos and the chaos created for nature must be subdued.

The excessive use of natural resources today, which results in the natural world's inability to fulfill its inhabitants' excessive demands, can be seen as paralleled by the lady's long-lasting rejection of the lover's attempts at seduction in the Renaissance sonnet sequence. New approaches to sixteenth-century sonnets may pave the way for considering recent ecological debates from a new and challenging perspective. The modern reader may be made more interested in sixteenth-century sonnets because they provide parallels with and cautions regarding the present situation — the depletion of natural resources and thus nature's gradual death —and the sixteenth-century conception of nature, which has a number of different dimensions.

\section{Harmony Regained}

Reevaluating Sidney's sonnet sequence may deepen modern readers' insights into ecology, love, and human relationships through reference to the psychology of the lovers and changes in climate. When we want a literary 
work (in this case Sir Philip Sidney's Astrophil and Stella) to help us think about what we do, how we live and develop, it is always pleasant to come across scenes of real life experiences, as well as natural scenes drawn from our environment. The change from seeing nature as an organic structure to seeing the non-living state of the universe is a significant matter now and it will continue to be a major concern in the future. Unless remaining energy sources are used more reasonably the future situation will be catastrophic. References to the sun as the father and the moon as the mother in sixteenth-century texts suggest protective figures. But today the effects of these planets are negative and disastrous events like tsunamis, earthquakes, and famines as a result of dry, infertile lands have become quite frequent. It is even more frightening to imagine the situation if no plans are made and carried out by all humanity to counteract global warming. John Tallmadge (2003) explains the deafness of human beings in his essay "Toward a Natural History of Reading" published in The Isle Reader: "Although the world 'speaks' we have grown deaf; we do not think of the other beings in nature as ethical equals, possessing valued attributes such as language, feelings, or character; as a result, we recklessly consume and despoil” (p. 283). Therefore, any attempt to make changes in the canon, revitalizing the curriculum and deepening our understanding and awareness of many great writers will not be in vain. It is difficult for those who do not have the chance to experience real riches and the harmony of nature to foresee even worse cases that await humanity.

Tallmadge's (2003) idea that "a full-scale natural history of reading would combine erudition (which means all the discursive knowledge gained from systematic reading) and engagement (which is the deliberate and systematic study of the referential world through direct encounter) in a balanced manner and eventuate, like classical natural history itself, in a narrative of illumination and discovery" (p. 291) coincides with Sidney's idea of the poet's role in conveying his observation about what nature presents and more. Tallmadge (2003) argues that "Narrative is the best mode of discourse for conveying the results of observation that is of disciplined subjectivity" (p. 291). When Sidney describes the poet's function as to instruct and delight, at the same time he defines him as someone more concrete than the philosopher and more universal than the historian. Although concerned with fact and accuracy, since natural history does not pretend to a wholly objective truth, the poet, and the critic as natural historian best collaborate in exploring nature writing. As Tallmadge (2003) further argues, "Nature writing always exemplifies and envisions new possibilities for human relations with the rest of the living world and hence serves a prophetic political purpose" (p. 292). As seen from the examples taken from Sidney's poetry, his sonnets present a view of nature as a balanced, non-exploitative system. It is rewarding and insightful to reevaluate Sidney's sonnets in the light of today's debates. It is high time to consider environmental problems from many different perspectives, including those of the literary works of the sixteenth century. Once again harmony needs to be achieved between nature and people.

\section{Conclusion}

Sidney in his sonnets taken from Astrophil and Stella deals with man-woman relationships, he portrays a rich background to the love affairs experienced in the 16th century. It is not all about the sonnets, though. When considered in the light of the effects of changing conditions in human life, environment and relationships in the sonnets provide a compelling reading for the modern readers. Sidney's language, symbols, nature images, and imagery in the sonnets make him a poet of nature in a wide sense. His sonnets help us reevaluate the world we live in, use and abuse of the natural resources, and the gift of nature that is bestowed on all human beings with a 
new approach, as suggested in this paper, an ecocritical approach. In conclusion, when read in an ecocritical perspective, Sidney's sonnets are rich, enlightening, and very resourceful.

\section{References}

Bradbrook, M. C. (1979). Shakespeare and the Elizabethan poetry: A study of his earlier work in relation to the poetry of the time. New York: Cambridge University Press.

Dutton, R. (1987). Selected writings: Astrophil and Stella, the defence of poesy and miscellaneous poems. Manchester: Carcanet Press.

Garrard, G. (2005). Ecocriticism. London: Routledge.

Gifford, T. (1999). Pastoral. New York: Routledge.

Lynn, W. (1967). The historical roots of our ecologic crisis. In Ecology and religion in history. New York: Harper and Row. Retrieved from http://www.siena.edu/ellard/historical_roots_of_ou r_ecologic.htm

Merchant, C. (1989). The death of nature. USA: Harper San Francisco.

Merchant, C. (2004). Reinventing Eden. New York: Routledge.

Naess, A. (1992). Ecology, community and lifestyle. (D. Rothenberg, Trans.). Cambridge: Cambridge University Press.

Shakespeare, W. (1997). Sonnets. In S. Greenblatt, (Ed.), The norton Shakespeare: Based on the Oxford edition. New York: Oxford University Press.

Tallmadge, J. (2003). Toward a natural history of reading. In P. Branch and M. S. Slovic (Eds.), The isle reader: Ecocriticism, 1993-2003. London: The University of Georgia Press.

Tillyard, E. M. W. (1972). The Elizabethan world picture. London: Penguin Books in association with Chatto and Windus. 